\title{
PENGARUH KONDISI OPERASI TERHADAP KONVERSI LIMBAH TANDAN KOSONG KELAPA SAWIT (TKKS) PADA PROSES HIDROTERMAL
}

\author{
THE EFFECT OF OPERATION CONDITIONS ON THE CONVERSION OF PALM \\ OIL EMPTY FRUIT BUNCH (EFB) IN HYDROTHERMAL PROCESSING
}

\author{
R. Sarwono, A.S.Putra, dan Y. Sudiyani \\ Pusat Penelitian Kimia - Lembaga Ilmu Pengetahuan Indonesia (LIPI) \\ Komplek PUSPIPTEK, Serpong Tang-sel (15314) \\ Email: Rach014@lipi.go.id \\ Diterima : 05 Agustus 2014, Revisi : 29 September 2014, Disetujui : 17 Oktober 2014
}

\begin{abstract}
ABSTRAK
Selulosa merupakan polimer yang dihasilkan oleh makhluk hidup terutama tumbuh-tumbuhan dengan jumlah yang sangat besar, dan sebagian besar menjadi limbah, seperti limbah pertanian, kehutanan dan sampah kota. Limbah tersebut selama ini belum termanfaatkan dengan baik. Biasanya dipakai sebagai bahan bakar dengan nilai kalor yang rendah. Penguraian limbah TKKS akan didapatkan bermacam-macam zat kimia yang mempunyai nilai lebih seperti glukosa, asam levulinat, erithosa dan bahan bakar cair dan gas. Proses hidrotermal mampu menguraikan limbah TKKS menjadi molekul kecil sebagai bahan bakar cair dan gas. Hidrotermal menggunakan media air yang berfungsi sebagai pelarut dan reaktan. Peruraian limbah TKKS dipengaruhi oleh kondisi operasi (tekanan, temperatur), jenis katalis, waktu reaksi, pengadukan dan rasio air dan padatan.Reaksi yang terjadi pada proses hidrotermal meliputi reaksi liquefaction, hydrolisis, dehydration, decarboxylation, condensation, aromatization dan polimerization. Hasil peruraian TKKS berupa padatan biochar, zat terlarut dalam air, dan gas. Umpan TKKS $1,8 \%$ memberi konversi sekitar $63 \%$, sedangkan pada konsentrasi katalis $\mathrm{Na}_{2} \mathrm{CO}_{3}$ 0,5\% memberi konversi yang cukup tinggi sekitar $75 \%$, pada temperatur operasi $400{ }^{\circ} \mathrm{C}$ memberi konversi sekitar 73\%, pada waktu reaksi 3 jam memberi konversi sekitar $70 \%$, sedangkan tekanan awal gas $\mathrm{N}_{2}$ tidak banyak berpengaruh terhadap konversi TKKS.
\end{abstract}

Kata kunci : TKKS, peruraian, konversi, hidrotermal, bahan terlarut air, gas.

\begin{abstract}
Cellulose is a polimer that produced in the living thing mainly from plantation with huge in amount, and also the majority from which is left as waste such as agricultural, forestry, food industries and municipal solid waste. Those wastes were not utilized properly yet, commonly used as a fuel
\end{abstract}

with lower calorific value. Degradation of empty fruit bunches (EFB) of palm oil yielded many kind of valuable chemicals such as glucose, levulinic acid,erythrose, and liquid fuel and gas. EFB is lignocellulosic waste that can be degraded into smaller molecule that can be used as liquid and gas fuel fraction. Hidrothermal used water as a medium that used as solvent and reactant. EFB degradation is influenced by operation condition such as temperature, pressure, catalyst, reaction time, stirring, and ratio of liquid and solid. The hydrothermal process reaction involved such as liquefaction, hydrolysis, dehydration,decarboxylation, condensation, aromatization, and polymerization. EFB degradation resulted solid as biochar, organic water soluble and gas. EFB concentration of $1.8 \%$ resulted $63 \%$ conversion, catalyst $\mathrm{Na}_{2} \mathrm{CO}_{3} 0.5 \%$ resulted $75 \%$, temperature operation of $400{ }^{\circ} \mathrm{C}$ gave $73 \%$ conversion, reaction time 3 hours gave $70 \%$ conversion, initial pressure of $N_{2}$ gas was not significantly influence to the EFB conversion.

Keywords : EFB, degradation, conversion, hydrothermal, water soluble, gas

\section{PENDAHULUAN}

Tandan kosong kelapa sawit(TKKS) merupakan limbah biomasa yang jumlahnya sangat banyak yang dihasilkan dari industri kelapa sawit. Penyusun utama TKKS adalah selulosa, hemi-selulosa dan lignin. Selulosa merupakan rantai monomer D-glukosa yang terikat dengan ikatan 1-4-glukosidik dengan rantai lurus, dengan formula glukosa $\left(\mathrm{C}_{6} \mathrm{H}_{10} \mathrm{O}_{5}\right)$ n. Sedangkan Lignin disusun oleh monomer katekol yang mempunyai gugus $\mathrm{OH}$, dengan formula $\mathrm{C}_{6} \mathrm{H}_{4}(\mathrm{OH})_{2}$. Hemiselulosa merupakan kopolimer dari karbohidrat unit (pentosa, arabinosa, xylosa, hexosa, galactosa, dan manosa) yang tersusun secara bercabang tiga dimensi ${ }^{(1)}$.

Produksi kelapa sawit Indonesia mengalami kenaikan dari 23,6 million metric tons (mmt) pada tahun 
2010/2011 menjadi 25,4 mmt pada tahun 2011/2012. Jumlah tandan kosong kelapa sawit (TKKS) dan pelepah sawit berpotensi bertambah banyak. Berat kering TKKS adalah sekitar $8 \%$ dari berat tandan buah segar (TBS), sedangkan satu batang pohon sawit akan menghasilkan satu pelepah baru setiap tiga minggu sekali $^{(2)}$. Menurut Hanim ${ }^{(3)}$ pelepah yang dihasilkan dari setiap hektar kebun kelapa sawit adalah sekitar 10,88 ton. TKKS dan pelepah kelapa sawit sampai saat ini belum dimanfaatkan secara optimal.

TKKS mempunyai kadar selulosa yang cukup tinggi yaitu sekitar $54,4 \%$, sedangkan pelepah mempunyai kadar selulosa sekitar $62,3 \%{ }^{(4)}$, dan kadar lignin yang cukup tinggi. Pada proses sakarifikasi untuk mendapatkan glukosa, kadar lignin yang tinggi akan mengganggu proses hidrolisa enzimatis. Lignin mempunyai pengaruh tidak baik terhadap jalannya proses hidrolisa enzimatis, karena lignin mengikat enzim yang akan menurunkan aktifitas enzim ${ }^{(5)}$, atau lignin menutup jalannya penetrasi enzim ke struktur selulosa karena enzim terikat oleh karbohidrat menjadi lignin-karbohidrat ${ }^{(}$. . Pada proses enzimatis perlu perlakuan awal (pretreatment) untuk menghilangkan ligninnya. Proses delignifikasi biasanya menggunakan asam atau basa yang sangat tidak ramah lingkungan.

Air pada kondisi subkritik adalah air pada kondisi suhu diatas titik didih dan dibawah temperatur kritisnya, dan tekanan dibawah tekanan kritisnya ${ }^{(7)}$. Dalam kondisi subkritis air mempunyai sifat yang berbeda dengan kondisi normal. Dalam kondisi subkritis air mengalami penurunan terhadap densitas dan dielectric constants, demikian juga $\mathrm{pKw}$ mengalami perubahan. Menurunnya dielectric constant menaikkan solubilitas molekul-molekul organik. Polaritas air dapat menaikkan kemampuan air untuk melarutkan bahan padat, cair dan gas. Dalam kondisi subkritik, air mempunyai sifat sebagai katalis asam atau basa ${ }^{(8)}$.

Pada proses hidrotermal, lignin tidak perlu dipisahkan, karena lignin akan terurai menjadi bentuk poliol seperti katekol, fenol, dan o-kresol ${ }^{(9)}$. Setelah itu proses hidrotermal tidak terpengaruh oleh tingginya kadar air dari bahan baku, karena hidrotermal menggunakan media air. Bahan baku dengan kadar air berapapun bisa diproses, tidak perlu proses pengeringan yang banyak memerlukan energi dan tenaga ${ }^{(0)}$. Bahan baku dengan berbagai macam komposisi pembentuknya juga bisa langsung diproses tanpa perlu proses perlakuan awal (pretreatment), semua komponen akan terkonversi dalam proses hidrotermal menjadi molekul yang lebih kecil.

Proses hidrotermal akan memecah molekul besar seperti selulosa, lignin dan hemiselulosa menjadi molekul kecil yang mempunyai rantai $\mathrm{C}$ dengan rentang antara $\mathrm{C}_{4}-\mathrm{C}_{10}$ yang bisa dipakai sebagai bahan bakar atau "biocrude" (11). Disamping itu reaksi yang penting adalah deosigenasi, yaitu pengurangan oksigen pada lignoselulosa dari $40 \%$ menjadi sekitar $10-15 \%$ untuk menaikkan nilai kalor ${ }^{(12)}$. Proses hidrothermal berlangsung sangat cepat dibandingkan dengan proses enzimatis, sehingga akan mempercepat proses dan dihasilkan fraksi cair yang lebih banyak. Proses pirolisis berlangsung pada suhu yang lebih tinggi dari $500{ }^{\circ} \mathrm{C}$ dan dihasilkan char, oil dan gas, gas yang merupakan prosi yang besar ${ }^{(13)}$. Pada proses pirolisa kontrol terhadap kondisi prosesnya lebih sukar dibandingkan proses hidrotermal.

Nilai kalor komponen lignoselulosa memiliki nilai kalor yang rendah, seperti selulosa sebesar 16,5 $\mathrm{MJ} / \mathrm{kg}$, hemiselulosa sekitar $16,7 \mathrm{MJ} / \mathrm{kg}$, dan lignin mempunyai nilai kalor $20,4 \mathrm{MJ} / \mathrm{kg}{ }^{(14)}$. Proses hidrotermal dapat menghasilkan bahan dengan rentang molekul $\mathrm{C}_{4}-\mathrm{C}_{10}$ yang dapat menaikan nilai kalor yang cukup tinggi sekitar $30 \mathrm{MJ} / \mathrm{kg}$ melalui reaksi degradasi yang diikuti reaksi deoksigenasi. Biomassa selulosa biasanya mengandung oksigen sekitar 40 $60 \%$. Agar bahan bakar cair yang dihasilkan mempunyai nilai kalor yang lebih tinggi, maka kadar oksigen harus dikurangi dalam hasil degradasi dengan proses deoksigenasi. Seperti bahan bakar konvensional, minyak bumi atau gas mempunyai kadar oksigen yang kurang dari $1 \%{ }^{(15)}$. Oleh karena itu proses deoksigenasi harus bersamaan dengan proses hidrolisa.

Proses hidrotermalmampu menguraikan limbah TKKS menjadi bahan bakar cair. Proses hidrotermal menggunakan media air pada kondisi sub- dan critical point ${ }^{(16}$. Pada kondisi ini air mempunyai sifat sebagai oksidator yang kuat. Oksigen dari air bisa berpindah ke atom karbon dari selulosa sehingga terjadi proses oksidasi menjadi $\mathrm{CO}_{2}$. Peruraian limbah selulosa dipengaruhi oleh kondisi operasi (tekanan, temperatur), jenis katalis, waktu reaksi dan rasio air dan padatan. Dengan manipulasi variabel operasi tersebut kita dapatkan hasil degradasi dari selulosa tersebut seperti hasil yang kita inginkan. Proses pada suhu tinggi sekitar $400{ }^{\circ} \mathrm{C}$ dan tekanan $25 \mathrm{Mpa}$, dan katalis alkali atau metal akan dihasilkan banyak gas, dan gas $\mathrm{H}_{2}$ hasil yang dominan ${ }^{(17)}$. Proses hidrotermal dengan suhu sedang sekitar $300-350^{\circ} \mathrm{C}$, dan tekanan $10-18 \mathrm{Mpa}$, selulosa didepolimerisasi menjadi biocrude, yang mempunyai nilai kalor yang tinggi dan bisa digunakan sebagai bahan bakar. Reaksi proses hidrotermal dimulai pada suhu $180{ }^{\circ} \mathrm{C}^{(18)}$. Reaksi pada proses hidrotermal meliputi reaksi liquefaction, hydrolisis, dehydration, decarboxylation, condensation dan polimerization. Walaupun mekanisme reaksi secara rinci belum bisa dijelaskan untuk biomassa ${ }^{(19)}$.

Dalam penelitian ini akan diekplorasi variabel operasi untuk mengetahui kinerja proses hidrotermal dalam kemampuannya untuk menguraikan TKKS menjadi biochar, bahan terlarut dan gas. 


\section{BAHAN DAN METODA}

\section{Bahan}

Bahan yang digunakan adalah limbah tandan kosong kelapa sawit (TKKS) yang berasal dari pabrik minyak kelapa sawit PTPN VIII Malingping, Banten. Natrium carbonat (p.a) sebagai katalis dan air suling.

\section{Peralatan}

Peralatan yang digunakan seperti terlihat pada Gambar 1. Reaktor berupa tabung dengan diameter dalam $2 \mathrm{~cm}$ dan panjang $1,7 \mathrm{~cm}$, dengan volume reaktor $55 \mathrm{ml}$ dan bisa dimasukkan kedalam oven secara keseluruhan, sehingga akan terjadi pemanasan secara merata, tidak dilengkapi dengan sistem pengaduk.

\section{Metoda Penelitian.}

Limbah TKKS dikeringkan kemudian dihaluskan dan diayak dengan ukuran partikel 1-3 $\mathrm{mm}$, sejumlah berat tertentu dimasukkan kedalam reaktor, ditambah katalis sebanyak $50 \mathrm{~mL}$. Reaktor di seal,ditutup rapat dan disekrup untuk menahan tekanan dari dalam. Gas nitrogen dengan tekanan tertentu dimasukkan ke dalam reaktor untuk memberi tekanan awal yang sesusai dengan yang diinginkan. Reaktor dimasukkan kedalam oven yang telah diatur temperaturnya. Proses dibiarkan berlangsung dalam waktu tertentu, sebagai waktu reaksi. Setelah reaksi selesai kemudian reaktor diambil dan didinginkan secepatnya dengan mengguyur dengan air untuk menghentikan proses reaksi. Reaktor dibuka dan larutan yang terjadi disaring untuk mengetahui berapa presentase limbah TKKS yang terdegradasi. Konversi adalah prosentase padatan TKKS yang berubah menjadi gas dan bahan terlarut dalam air. Penelitian dilakukan dalam sekali running. Sedangkan kondisi operasi yang dicobakan adalah pengaruh prosentase umpan (perbandingan padatan dan air), prosentase katalis $\mathrm{Na}_{2} \mathrm{CO}_{3}$, pengaruh temperatur operasi, waktu reaksi dan tekanan awal gas inert $\mathrm{N}_{2}$.

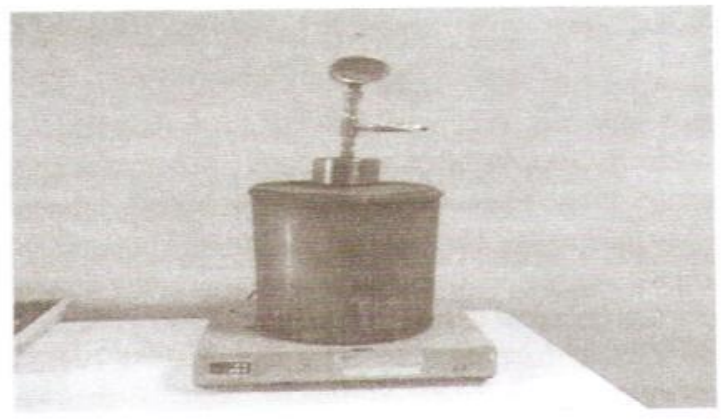

Gambar 1. Peralatan untuk peruraian limbah TKKS

\section{HASIL DAN PEMBAHASAN}

Proses hidrotermal merupakan proses tiruan seperti proses yang berlangsung pada kerak bumi, yaitu peruraian zat organik yang berasal dari tanaman yang terkubur dalam perut bumi selama bertahun-tahun. Tanaman tersebut mengalami proses peruraian karena terendam air dengan tekanan dan temperatur yang tinggi, sehingga tanaman tersebut mengalami peruraian menjadi batubara dengan proses yang sangat lambat, sampai jutaan tahun. Dalam keadaan terendam air dan temperatur dan tekanan naik secara gradual proses peruraian berlangsung secara termokimia. Dalam proses ini kandungan oksigen dan hidrogen dalam bahan akan berkurang,sedangkan $\mathrm{H}_{2} \mathrm{O}$ dan $\mathrm{CO}_{2}$ keluar dari structur molekul ${ }^{(20)}$. Selanjutnya proses ini dipakai dalam proses hidrotermal, untuk mempercepat peruraian zat organik tersebut perlu memberi temperatur dan tekanan yang tinggi, yaitu mendekati kondisi kritisnya, maka reaksi akan berlangsung lebih cepat.

Proses hidrotermal mampu menguraikan TKKS menjadi tiga fraksi yaitu, produk padat, zat terlarut air dan gas. Reaksi yang berlangsung pada proses peruraian TKKS meliputi hidrolisis, liquefaction, dehidrasi, deoksigenasi, polimerisasi dan hidrogenasi ${ }^{(21)}$. Reaksi ini berlangsung secara bersamaan yang belum bisa dijelaskan secara rinci. Proses karbonisasi didominasi proses dehidrasi, glukosa dihilangkan airnya menjadi biochar dengan kandungan karbon yang tinggi ${ }^{(19)}$.

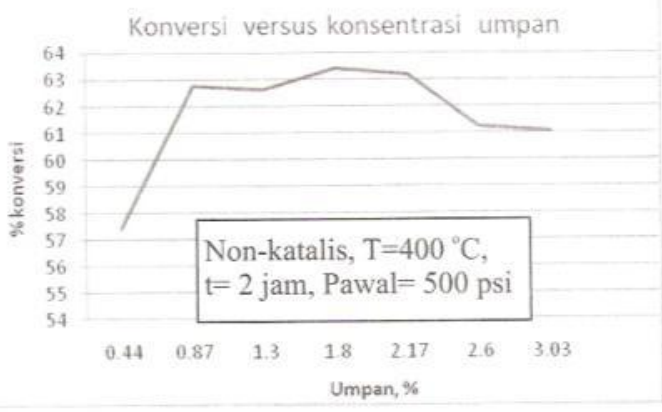

Gambar 2. Konversi TKKS menurut konsentrasi umpan

Makin tinggi konsentrasi umpan konversi menjadi zat terlarut dan gas semakin meningkat. Reaksi peruraian TKKS dipengaruhi oleh banyak faktor seperti konsentrasi umpan, temperatur, waktu reaksi, katalis, pengadukan dan tekanan dalam reaktor. Variabel proses ini saling mempengaruhi satu sama lain. Karena reaktor batch tertutup maka setiap peningkatan temperatur akan meningkatkan juga tekanan didalam reaktor. Tekanan juga akan berpengaruh terhadap kecepatan reaksi tertentu.

Perbandingan antara padatan biomasa dan air 
sangat berpengaruh terhadap konversi padatan menjadi zat terlarut dan gas. Terlalu tinggi kandungan padatan dalam umpan akan menyebabkan proses kontak antara air dan padatan terhambat. Untuk mengoptimalkan produksi biochar maka kandungan padatan yang diproses bisa tinggi ${ }^{(20)}$.

Makin tinggi umpan yang bisa diproses maka proses karbonatasi akan makin efisien, karena dalam satu siklus operasi akan diproses bahan baku dengan konsentrasi yang tinggi, namun kemampuan proses hidrotermal juga terbatas, seperti terlihat pada Gambar 2. Konsentrasi umpan $1,8 \%$ memberi konversi yang paling tinggi yaitu sekitar $63 \%$. Artinya padatan TKKS akan terkonversi menjadi zat terlarut dalam air dan gas dan sisanya biochar dengan presentasi karbon yang meningkat.

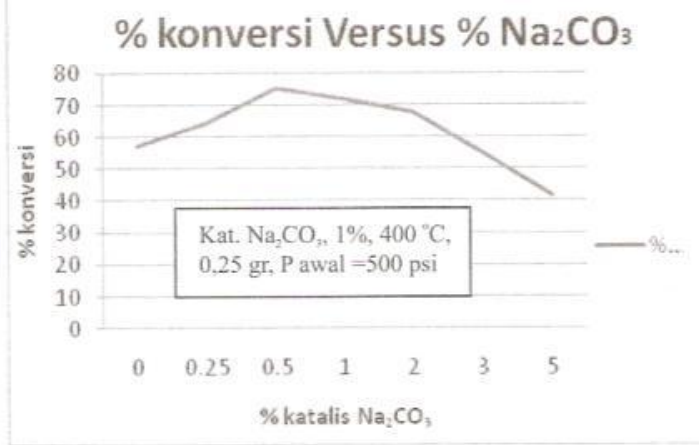

Gambar 3. Konversi TKKS pada perubahan konsentrasi katalis

Katalis sangat berpengaruh terhadap kemampuan air untuk melarutkan TKKS menjadi zat terlarut. Namun makin tinggi konsentrasi katalis $\mathrm{Na}_{2} \mathrm{CO}_{3}$ konversi juga menurun. Konsentrasi katalis 0,5\% memberi konversi yang paling tinggi yaitu sekitar $75 \%$, TKKS menjadi zat terlarut dan gas makin besar, seperti terlihat pada Gambar 3.

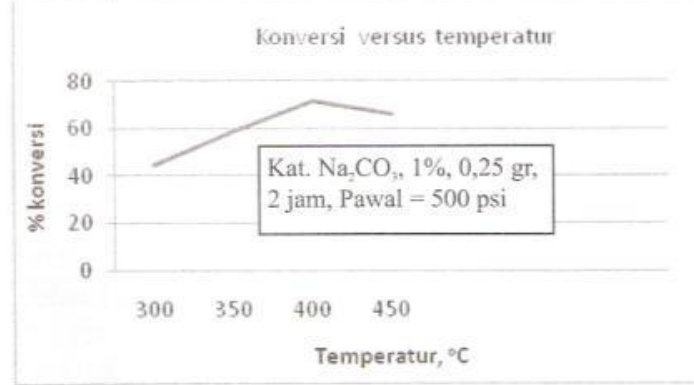

Gambar 3. Konversi TKKS pada perubahan temperatur proses.

Temperatur proses juga sangat berpengaruh terhadap kemampuan air untuk melarutkan TKKS. Pada temperatur $400{ }^{\circ} \mathrm{C}$ mempunyai konversi yang paling tinggi, yaitu sekitar 71\%, seperti terlihat pada Gambar 4 .
Temperatur dinaikan konversi menurun lagi. Temperatur merupakan parameter proses yang sangat berpengaruh terhadap karakterisasi produk yang dihasilkan. Makin tinggi temperatur menyebabkan reaksi lebih cepat, terutama pada proses hidrolisa biomasa menjadi bahan terlarut. Waktu dan temperatur reaksi sangat berpengaruh terhadap kandungan karbon dalam hasil biochar ${ }^{(19)}$.

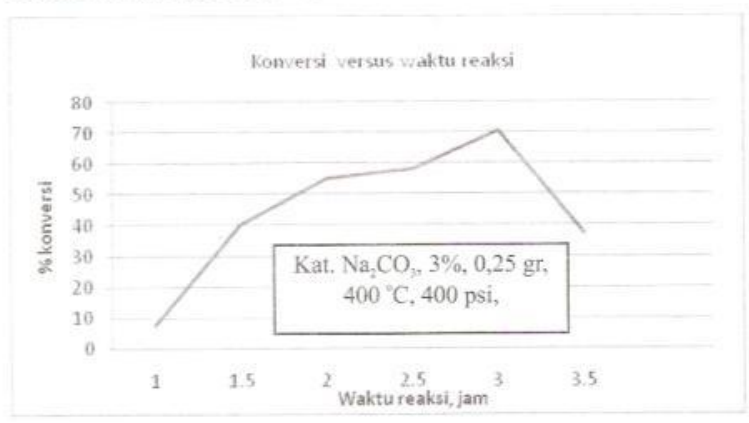

Gambar 5. Konversi TKKS terhadap perubahan waktu proses.

Waktu reaksi juga sangat berpengaruh terhadap konversi TKKS. Waktu reaksi memberi kesempatan berlangsungnya reaksi. Waktu reaksi 3 jam memberi konversi yang paling tinggi, sekitar $71 \%$, seperti terlihat pada Gambar 5. Penambahan waktu reaksi menurunkan konversi TKKS.

Waktu reaksi tidak sama dalam setiap pemakaian bahan baku yang berbeda, karena mempunyai susunan yang berbeda juga. Setiap bahan baku lignoselulosa mempunyai waktu reaksi optimum tidak sama. Waktu reaksi sangat bervariasi, dari 1 sampai $72 \mathrm{jam}^{(22)}$. Proses dengan waktu tinggal pendek kurang dari 1 jam juga dilakukan dan menghasilkan produk dengan nilai panas yang makin naik ${ }^{(19)}$.

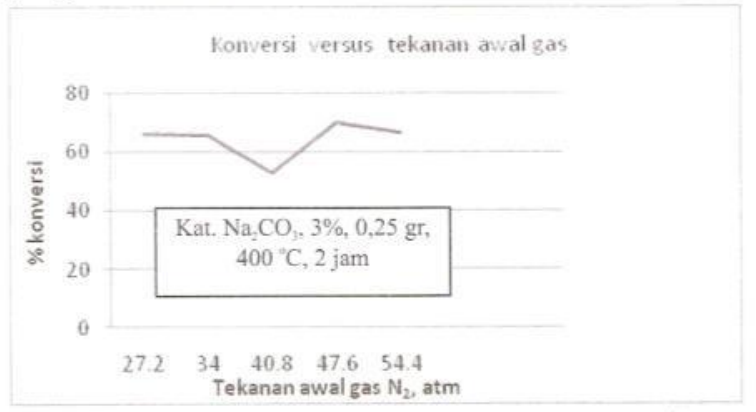

Gambar 6. Konversi TKKS terhadap tekanan awal $\mathrm{N}_{2}$ dalam reaktor.

Tekanan gas akan berpengaruh terhadap sifat air, dielectric constant semakin menurun akan menyebabkan meningkatkan daya larut terhadap zat organik yang akan membantu melarutkan zat-zat organik. Polaritas air menaikkan kemampuan air untuk 
melarutkan bahan padat, cair dan gas, dan juga air dalam kondisi subkritis mempunyai sifat sebagai katalis asam atau basa ${ }^{(8)}$. Tekanan awal gas $\mathrm{N}_{2}$ tidak banayk pengaruhnya terhadap konversi TKKS, seperti terlihat pada Gambar 6. Kemungkinan karena temperaturnya sudah diatas suhu kritisnya maka tekanan sudah tidak banyak pengaruhnya.

Dibandingkan dengan proses biologis seperti proses anaerobik, proses hidrotermal mempunyai keuntungan, seperti waktu reaksi lebih singkat dalam orde jam. Proses hidrotermal menggunakan temperatur tinggi yang akan menghilangkan pathogen dan kontaminan lainnya yang membuat produk lebih bersih dan steril $^{(23)}$. Dibandingkan dengan proses pirolisa, proses pirolisa menggunakan umpan dengan kadar air yang rendah, sedangkan proses hidrotermal menggunakan umpan dengan kadar air berapa saja bisa diproses,tidak perlu ada proses pengeringan yang banyak mengkonsumsi energi ${ }^{(19)}$. Adanya air yang ada pada kondisi superkritis pada kenaikkan temperature akan menaikkan daya hidrolisa terhadap zat organik ${ }^{(24)}$. Pada reaksi hidrolisa air akan membantu memotong ikatan kimia dari molekul besar seperti selulosa.

Temperatur reaksi merupakan parameter yang sangat berpengaruh pada karakterisasi produk yang dihasilkan. Naiknya temperatur akan menaikkan laju reaksi, dan juga waktu reaksi berpengaruh terhadap kualitas produk yang dihasilkan ${ }^{(19)}$.

Untuk perbandingan antara padatan dan air atau konsentrasi umpan, bila konsentrasi umpan tinggi maka akan terjadi konsentrasi monomer yang meningkat yang akan mempermudah reaksi polimerisasi lebih awal. Padatan hendaknya terendam dalam air namun campuran harus bisa diaduk untuk memeratakan reaksi ${ }^{(20)}$.

\section{KESIMPULAN}

Proses hidrotermal mampu menguraikan TKKS menjadi bahan terlarut dan gas. Banyak senyawa yang terjadi dari terurainya TKKS. Fraksi yang larut dalam air merupakan senyawa organik yang kecil-kecil diharapkan merupakan senyawa yang bisa dipakai sebagai bahan bakar cair.

Umpan TKKS 1,8\% memberi konversi yang tinggi sekitar $63 \%$, konsentrasi katalis $\mathrm{Na}_{2} \mathrm{CO}_{3}$ memberi konversi yang tinggi sekitar $75 \%$, temperatur operasi $400^{\circ} \mathrm{C}$ member konversi sebesar $73 \%$, sedangkan waktu reaksi 3 jam member konversi sebesar $70 \%$, tekanan awal gas $\mathrm{N}_{2}$ tidak begitu berpengaruh terhadap konversi TKKS. Produk biochar merupakan produk karbon yang berwarna hitamkecoklatan yang pekaiannya untuk reklamasi tanah, dan bila diaktifkan menjadi karbon aktif.
Proses hidrotermal mempunyai banyak keuntungan dibandingkan dengan proses yang lain. Dibandingkan dengan proses biologi, hidrotermal mempunyai waktu tinggal yang lebih singkat. Jika dibandingan dengan proses pirolisa, suhu operasi proses hidrotermal lebih rendah dari pada proses pirolisa dan proses hidrotermal mampu memproses bahan baku dengan kadar air yang tinggi, jadi tidak perlu proses pengeringan yang banyak memerlukan energi.

\section{DAFTAR PUSTAKA}

1. M. Brebu, and C. Vasile, (2010). Thermal Degradation of Lignin- A Review. Cellulose Chem.Technol.,44(9), 353-363.

2. D. Sheil, A. Casson, E. Meijaard, M. Van Noordwijk, J. Gaskell, J.S. Groves, K. Wertz, M. Kanninem, (2009). The impacts and opportunities of oil palm in Southeast Asia, CIFOR, Bogor, Indonesia.

3. S.S. Hanim, M.A.M. Noor, A. Rosma, (2010). Effect of autohydrolysis and enzymatic treatment on oil palm (Elaeis guineensis Jacq.) frod fibrea for xylose and xylooligosaccharides production, Bioresource Technology, Article in Press, doi: 10.1016/j.biortech.2010.08.017.

4. C.S Goh, K.T. Tan, K.T. Lee, S. Bhatia, (2010). Bio-ethanol from lignocellulose : status, perspectives and challenges in Malaysia, Bioresource Technology, 101 (13): 4834-4841.

5. U. Moilanen, M. Kellock, S. Galkin, L. Viikari, ( 2011). The laccase-catalyzed modification of lignin for enzymatic hydrolysis. Enzyme Microb Technol. 2011 Dec 10;49(6-7):492-8.

6. Z. Yu, H. Jameel, H.M. Chang, S., Park, (2012).A Study in lignin Inhibition for Enzymatic Hydrolysis of Woody Biomass. 12AIChE Annual Meeting, 11 Februari 2012, Pittsburgh, PA, USA.

7. S. Adachi, (2009). Properties of Subcritical Water and Its Utilization. Foods Food Ingredients J.Jpn. Vol. 214, No.2:

8. Wahyudiono, S. Machmudah, and M. Goto.(2013). Utilization of Sub and Supercritical Water Reactions in Resource Recovery of Biomass Wastes. Engineering J. Vol. 17, Issue 1. Online at http://www.engj.org/. DOI: 10.4186 /ej.2013.17.1.1

9. Wahyudiono, T.Kanetake, M.Sasaki, and M.Goto,(2007). Decomposition of lignin model compound under hydrothermal conditions. Chem.Eng.Technol.,30:1113-1122. 
10. J.M. Antal, S. Allen, D. Schulman, X. Xu, and R.Divilio,(2000). biomass gasification in supercritical water. ind eng chem res;39:40-9.

11. W. Feng, J. Hedzer, and J.S. Kooi, (2004). Phase equilibria for biomass conversion processes in subcritical and supercritical water. Chem Eng J; 98: 105-13.

12. M. Watanabe, H. Inomata, M. Osada, T. Sato, T. Adschiri, and K.Arai, (2003). catalytic effects of naoh and $\mathrm{zrO}_{2}$ for partial oxidative gasification of $\mathrm{n}$-hexadecane and lignin in supercritical water. fuel; 82: 545-52.

13. J.A. Lomax, J.M. Commandeur, P.W. Arisz, J.J. Boon, (1991). Characterization of oligomers and sugar ring-cleavage products in the pyrolysate of cellulose.J.Anal.appl.Pyrolysis, 20:848-889.

14. A.A. Peterson, F.Vogel, R.P. Russel, P.Lachance, M.Froling, M.J. Antal,jr, and J.W. tester, (2008). Thermochemical biofuel production in hydrothermal media: A review of sub- and supercritical water technologies. energy environ. sci.1:32-65

15. A.M. Aitani (2004). Oil refining and products, in Encyclopedia of Energy, ed. C.J. Cleveland, Elsevier, New York, vol.4, pp. 715-729.

16. F. Jin, and H. Enamoto, (2009). Hydrothermal conversion of Biomass into value-added products: Technology That mimics nature. BioResources, 4(2), 704-713.

17. Y. Ishida, et al. (2005). Effective and Selective hydrogen formation from biomass through hydrothermal reaction. 3rd International Energy
Conversion Engineering Conference. 15-18 August 2005. San Francisco, Ca.

18. M. Sakaguchi, K. Laursen, H. Nakagawa, and K. Miura, (2008). Hydrothermal upgrading of Loy Yang Brown coal- Effect of upgrading conditions on the characteristics of the products. Fuel Proceesing Technology, 89, 391-396

19. A. Funke, F. Ziegler (2010). Hydrothermal carbonization of biomass: a summary and discussion of chemical mechanisms for process engineering. Biofpr. 4, 160-177.

20. A. Krause, (2010). Hydrothermale Carbonisierung Organischer Retoffe: Machbarkeitsbetrachtung der technischen Realisierungsmoglichkeiten in der Region Kagera Tansania. s.1.:TU Berlin.

21. C-H. Zhou, X. Xia, C-X. Lin, D-S. Tong, and J. Beltramini, (2011). Catalytic conversion of lignocellulosic biomass to fine chemicals and fuels. Chem.Soc.Rev., 40, 5588-5617.

22. Z. Robbiani, (2013). Hydrothermal carbonization of biowaste / fecal sludge. Master Thesis. Swiss Federal Institute of Technology, Zurich.

23. J.A. Libra, et al. (2011). Hydrothermal carbonization of biomass residuals: a comparative review of the chemistry, processes and applications of wet and dry pyrolysis. Biofuel, 2(1): 89-124.

24. A.Funke, (2012). Hydrothermale Verfahren (H TC, V TC) in der energetische Verwertungskette.Berlin: 73. Symposium des ANSe.V. 